\title{
MORPHOMETRIC ANALYSIS OF BILATERAL VARIATIONS IN THE ANATOMY OF FOOT
}

\author{
Abhilasha ${ }^{* 1}$, Ajitpal Singh ${ }^{2}$. \\ ${ }^{* 1}$ Demonstrator, Department of Anatomy, J.C.D. Dental College, Sirsa, Haryana, India. \\ 2 Professor and Head, Department of Anatomy, Desh Bhagat Dental College And Hospital, Desh \\ Bhagat University, Mandi Gobindgarh Punjab, India
}

\section{ABSTRACT}

Introduction: Foot dynamic anthropometry has a vital role in medical rehabilitation, sport science, and footwear design among others. There is wide diversity in human foot size and shape depending upon race, age, sex etc. It is known that one's foot size changes with age. Children and teenagers grow one to three foot sizes each year

Materials and Methods: Present research has been designed to study the bilateral variations in the anatomy of foot. The study is conducted on 400 young females ranging in age from $5.00-20.99$ years, residing in Haryana region of India. The foot length and foot width dimensions (and derived foot index) of female subjects are quantitatively analyzed to find bilateral asymmetry. A total of 400 female subjects divided into eight age groups,

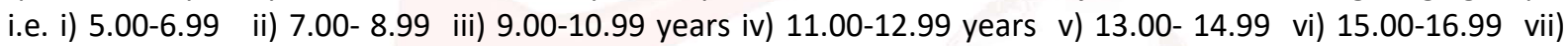
17.00-18.99 viii) 19.00-20.99 were measured for Foot length and foot breadth using standard anthropometric techniques. Percentage distribution of asymmetry is found using the formula of Relative index of asymmetry (RIA) given by wolansky (1965).

Results and Conclusion: Results indicate the increasing trends in foot length and foot breadth in all the age groups. Applying Student's t-test reveals statistically significant bilateral asymmetry in foot length of all the age groups except for age group ranging from 9.00-10.99 whereas bilateral asymmetry for foot breadth is nonsignificant for three groups i.e. 5.00-6.99, 9.00-10.99 and 15.00-16.99. Present observation can be used as base line data for the use of forensic science and foot shape.

KEY WORDS: Foot Length, Foot Width, Foot Index, Foot Anthropometry, Bilateral variations, Relative Index of Asymmetry.

Address for Correspondence: Dr. Abhilasha Setia, Demonstrator, Department of Anatomy, J.C.D. dental college, Sirsa, Haryana, India. Ph: 9466593001,E-Mail: abhilasha.setia@gmail.com

\begin{tabular}{|c|c|c|}
\hline \multicolumn{3}{|c|}{ Access this Article online } \\
\hline \multirow{2}{*}{$\begin{array}{l}\text { Quick Response code } \\
\text { Dol: } 10.16965 / \text { iiar.2017.201 }\end{array}$} & \multicolumn{2}{|c|}{$\begin{array}{l}\text { Web site: International Journal of Anatomy and Research } \\
\qquad \text { ISSN 2321-4287 } \\
\text { www.ijmhr.org/ijar.htm }\end{array}$} \\
\hline & $\begin{array}{l}\text { Received: } 25 \text { Mar } 2017 \\
\text { Peer Review: } 26 \text { Mar } 2017 \\
\text { Revised: None }\end{array}$ & $\begin{array}{l}\text { Accepted: } 08 \text { May } 2017 \\
\text { Published (O): } 31 \text { May } 2017 \\
\text { Published (P): } 31 \text { May } 2017\end{array}$ \\
\hline
\end{tabular}

\section{INTRODUCTION}

Foot dynamic anthropometry has a vital role in medical rehabilitation, sport science, and footwear design among others [1].There is wide diversity in human foot size and shape depending upon race, age, sex etc. It is known that one's foot size changes with age. Children and teenagers grow one to three foot sizes each year[2].
Ideally, foot measurements should be taken separately for each size to allow the proper shoe fit across all sizes [3]. Various dimensions of each foot of an individual often differ from one another - thus one particular size of a shoe might fit one foot but not the other, even though there may not be significant bilateral differences in the dimensions [4]. For proper designing of 
footwear, foot size and proportion is of great importance for proper fit and comfort of foot within the shoe. Generally it is also proved that adult male foot dimensions are larger than the adult female foot dimensions. Ewunonu et al. have shown significantly higher mean values of foot length and foot breadth in males than females [5]. The study further indicated that in both males and females, right foot is longer and wider than left foot. In majority of the elderly people, the feet are considerably broader than the footwear available [6]. Manna et al found no significant difference in foot dimensions between the right and left foot of Bengalee (Indian) female subjects except the foot breadth [7]. For 18 years and above, Nigerian feet are longer and broader in males than in females. Both Nigerian males and females feet had higher mean foot length than that of Caucasians [8]. Similar observation was made by Oladipo et al. who found right foot 2 to $3 \mathrm{~mm}$ longer and wider, and suggested that the left and right shoe shape should not be symmetrical while designing footwear [9]. No statistically significant difference in right and left foot length in females of Gulbarga, Karnataka, are observed [10]. Contributing studies on foot size and proportions are useful in forensic, designing shoe and orthopedic applications but data on bilateral variations of foot length and foot breadth for Indian populations is still lacking which emphasize the need to conduct the present study.

Aims and objectives: Keeping in view the importance of foot anthropometry the present study aims to report the foot length, foot breadth and foot index of the left and right feet and find bilateral differences and to see if there are any age related changes in these measurements.

\section{MATERIALS AND METHODS}

The data of present study is comprised of 400 young Haryanvi females ranging in age from 5.00 to 20.99 years. To see the age related changes in foot size and proportion the sample is further divided into eight age groups i) (5.006.99 years), ii) (7.00- 8.99 years), iii) (9.00-10.99 years), iv) (11.00-12.99 years) v) (13.00-14.99) vi) $15.00-16.99$ vii) $17.00-18.99$ viii) $19.00-20.99$. The subjects are chosen on simple random basis from Haryana including Sirsa, Fathehabad,
Hisar, Rohtak, Bhiwani, Sonipat, Karnal, Ambala and Jind Districts. Prior informed consent for the study is obtained from subjects (if adult) otherwise from their parents before their participation in the study. Ethical approval is taken from the university institutional ethical committee before the commencement of study. The subjects are advised not to change their position while measurements being taken. Foot length and foot breadth of the female subjects is measured using standard anthropometric techniques given by Lohman et al [11]. Foot length is measured using measuring steel tape and Sliding caliper is used for measuring the foot width. Foot index of both right and left feet is also calculated. The data is analyzed to find mean, standard deviation. Subjects with apparent foot anomalies, inflammation, trauma, deformities and surgery (if any) are excluded because of their unsuitability for the investigation.

Equipments used: Spreading caliper, Measuring tape.

\section{Somatometric measurements}

Foot Length: It is distance measured from acropodian (it is the most forwardly projecting point on the head of the first or second toe whichever is larger when the subject stands erect) to pternion( it is the most backwardly projecting point on the heel) [12].

Foot Breadth: The foot breadth is measured as the distance between medial margin of the head of the first metatarsal and lateral margin of the head of the fifth metatarsal ${ }^{12}$.

Foot index (FI): Is calculated as foot width divided by foot length and multiplied by 100 (Jung et al.2001) [13].

\section{Foot Indices:}

\section{Foot index $=$ Foot breadth $\times 100$ Foot length}

Relative Index of Asymmetry (RIA): Percentage distribution of asymmetry in the foot dimensions i.e. foot length, foot breadth and foot index is calculated using the formula of Relative Index of Asymmetry (RIA) given by Wolanski (1965) [14].

$$
R I A=\frac{2(D) \times 100}{X_{R}+X_{L}}
$$


Where $D$ is the mean difference between right and left side measurement of the body. Individual differences are calculated as higher value minus lower value.

$X_{R}$ is the mean for right side of the body.

$X_{L}$ is the mean for the left side of the body.

\section{OBSERVATIONS}

Within sample variation occurs more for foot length in both right and left feet as compared to foot width. Percentage distribution of asymmetry in the foot dimensions is calculated and is resulting in the significant values for all three foot dimensions. Relative Index of Asymmetry (RIA) values of foot index are significant for all the age groups and are explained in table no.3, 4 and 5. RIA values of foot length are significant for all age groups except for the age group 9.00-10.99 and 7.00-8.99. Similarly RIA values for foot breadth dimensions are significant for all age groups except for the age group 9.0010.99.The $t$-values listed in Table 6 shows that there is statistically significant bilateral difference in the above mentioned foot measurements. Applying Student's t-test reveals statistically significant bilateral asymmetry in foot length of all the age groups except for age group ranging from 9.00-10.99 whereas bilateral asymmetry for foot breadth is not significant for three groups i.e. 5.00-6.99, 9.00-10.99 and 15.0016.99. Most statistically significant value for foot length and foot breadth is $11.82507^{* *}$ and $11.35607^{* *}$ respectively is found in the same age group i.e. 13.00-14.99. Least significant value for foot length is 2.972253* and foot breadth is $5.4220594 *$ found in age group $7.00-$ 8.99 and $17.00-18.99$ respectively.

Table 1: Mean and Standard Deviation (SD) of Foot length, Foot breadth and Foot Index of Right Foot.

\begin{tabular}{|c|c|c|c|c|c|c|c|}
\hline $\begin{array}{c}\text { Age Group } \\
\text { (In Years) }\end{array}$ & \multirow{2}{*}{$\mathrm{N}$} & \multicolumn{2}{|c|}{ Foot length $(\mathrm{cm})$} & \multicolumn{2}{|c|}{ Foot breadth $(\mathrm{cm})$} & \multicolumn{2}{c|}{ Foot Index } \\
\cline { 3 - 8 } & & Mean & SD & Mean & SD & Mean & SD \\
\hline $5.00-6.99$ & 50 & 18.002 & 0.523 & 5.876 & 0.4133 & 32.62 & 1.841 \\
\hline $7.00-8.99$ & 50 & 19.966 & 0.504 & 5.412 & 0.248 & 27.1 & 0.865 \\
\hline $9.00-10.99$ & 50 & 20.72 & 1.02 & 5.688 & 0.352 & 27.45 & 1.074 \\
\hline $11.00-12.99$ & 50 & 22.436 & 0.583 & 6.556 & 0.323 & 29.2 & 0.822 \\
\hline $13.00-14.99$ & 50 & 23.268 & 0.798 & 7.308 & 0.138 & 31.43 & 0.984 \\
\hline $15.00-16.99$ & 50 & 23.638 & 0.855 & 7.07 & 0.329 & 29.9 & 0.706 \\
\hline $17.00-18.99$ & 50 & 24.2 & 0.938 & 7.026 & 0.41 & 29.05 & 1.642 \\
\hline $19.00-20.99$ & 50 & 23.886 & 1.145 & 7.084 & 0.463 & 29.69 & 2.002 \\
\hline
\end{tabular}

Table 2: Mean and Standard Deviation (SD) of Foot length, Foot breadth and Foot Index of Left Foot.

\begin{tabular}{|c|c|c|c|c|c|c|c|}
\hline $\begin{array}{c}\text { Age Group } \\
\text { (In Years) }\end{array}$ & \multirow{2}{*}{$\mathrm{N}$} & \multicolumn{2}{|c|}{ Foot length $(\mathrm{cm})$} & \multicolumn{2}{c|}{ Foot breadth $(\mathrm{cm})$} & \multicolumn{2}{c|}{ Foot Index } \\
\cline { 3 - 8 } & & Mean & SD & Mean & SD & Mean & SD \\
\hline $5.00-6.99$ & 50 & 17.644 & 0.492 & 6.204 & 0.36 & 35.164 & 1.827 \\
\hline $7.00-8.99$ & 50 & 19.62 & 0.411 & 5.904 & 0.245 & 30.087 & 0.939 \\
\hline $9.00-10.99$ & 50 & 19.664 & 0.929 & 6.14 & 0.412 & 31.202 & 0.937 \\
\hline $11.00-12.99$ & 50 & 21.826 & 0.554 & 7.006 & 0.249 & 32.101 & 0.868 \\
\hline $13.00-14.99$ & 50 & 21.724 & 0.499 & 7.584 & 0.107 & 34.928 & 0.946 \\
\hline $15.00-16.99$ & 50 & 22.688 & 0.804 & 7.426 & 0.265 & 32.739 & 0.796 \\
\hline $17.00-18.99$ & 50 & 23.144 & 0.923 & 7.422 & 0.329 & 32.106 & 1.68 \\
\hline $19.00-20.99$ & 50 & 22.974 & 0.987 & 7.632 & 0.486 & 33.273 & 2.466 \\
\hline
\end{tabular}

Table 3: Relative Index of Asymmetry (RIA) of Foot length.

\begin{tabular}{|c|c|c|c|c|c|}
\hline $\begin{array}{c}\text { Age Group } \\
\text { (In Years) }\end{array}$ & $\mathrm{N}$ & $\begin{array}{c}\text { Mean length } \\
\text { right (cm) }\end{array}$ & $\begin{array}{c}\text { Mean length } \\
\text { left (cm) }\end{array}$ & $\begin{array}{c}\text { Difference in } \\
\text { mean length }\end{array}$ & RIA \\
\hline $5.00-6.99$ & 50 & 18.002 & 17.644 & 0.358 & 2.008 \\
\hline $7.00-8.99$ & 50 & 19.966 & 19.62 & 0.346 & 1.748 \\
\hline $9.00-10.99$ & 50 & 20.72 & 19.664 & 0.09 & 0.446 \\
\hline $11.00-12.99$ & 50 & 22.436 & 21.826 & 0.61 & 2.756 \\
\hline $13.00-14.99$ & 50 & 23.268 & 21.724 & 1.544 & 6.863 \\
\hline $15.00-16.99$ & 50 & 23.638 & 22.688 & 0.95 & 4.101 \\
\hline $17.00-18.99$ & 50 & 24.2 & 23.144 & 1.56 & 6.59 \\
\hline $19.00-20.99$ & 50 & 23.886 & 22.974 & 0.912 & 3.892 \\
\hline
\end{tabular}

Table 4: Relative Index of Asymmetry (RIA) of Foot breadth.

\begin{tabular}{|c|c|c|c|c|c|}
\hline $\begin{array}{c}\text { Age Group } \\
\text { (In Years) }\end{array}$ & $\mathrm{N}$ & $\begin{array}{c}\text { Mean breadth } \\
\text { right }(\mathrm{cm})\end{array}$ & $\begin{array}{c}\text { Mean breadth } \\
\text { left }(\mathrm{cm})\end{array}$ & $\begin{array}{c}\text { Difference in } \\
\text { mean breadth }\end{array}$ & RIA \\
\hline $5.00-6.99$ & 50 & 5.876 & 6.204 & 0.328 & 5.43 \\
\hline $7.00-8.99$ & 50 & 5.412 & 5.904 & 0.492 & 8.695 \\
\hline $9.00-10.99$ & 50 & 5.688 & 6.14 & 0.059 & 0.997 \\
\hline $11.00-12.99$ & 50 & 6.556 & 7.006 & 0.45 & 6.637 \\
\hline $13.00-14.99$ & 50 & 7.308 & 7.584 & 0.276 & 3.706 \\
\hline $15.00-16.99$ & 50 & 7.07 & 7.426 & 0.356 & 4.193 \\
\hline $17.00-18.99$ & 50 & 7.026 & 7.422 & 0.396 & 5.481 \\
\hline $19.00-20.99$ & 50 & 7.084 & 7.632 & 0.548 & 7.447 \\
\hline
\end{tabular}

Table 5: Relative Index of Asymmetry (RIA) of Foot Index.

\begin{tabular}{|c|c|c|c|c|c|}
\hline $\begin{array}{c}\text { Age Group } \\
\text { (In Years) }\end{array}$ & $\mathrm{N}$ & $\begin{array}{c}\text { Mean Index } \\
\text { right }(\mathrm{cm})\end{array}$ & $\begin{array}{c}\text { Mean Index } \\
\text { left }(\mathrm{cm})\end{array}$ & $\begin{array}{c}\text { Difference in } \\
\text { mean Index }\end{array}$ & RIA \\
\hline $5.00-6.99$ & 50 & 32.627 & 35.164 & 2.537 & 7.484 \\
\hline $7.00-8.99$ & 50 & 27.1001 & 30.0872 & 2.987 & 10.446 \\
\hline $9.00-10.99$ & 50 & 27.453 & 31.2028 & 3.7497 & 12.785 \\
\hline $11.00-12.99$ & 50 & 29.2073 & 32.101 & 3.7898 & 12.363 \\
\hline $13.00-14.99$ & 50 & 31.4356 & 34.9289 & 3.4932 & 11.4314 \\
\hline $15.00-16.99$ & 50 & 29.9052 & 32.7399 & 2.3469 & 7.4926 \\
\hline $17.00-18.99$ & 50 & 29.0516 & 32.1063 & 3.0547 & 9.9895 \\
\hline $19.00-20.99$ & 50 & 29.6935 & 33.2731 & 3.5795 & 11.3707 \\
\hline
\end{tabular}


Table 6: $t$ Values of Foot Measurements.

\begin{tabular}{|c|c|c|c|}
\hline $\begin{array}{c}\text { Age Group } \\
\text { (In Years) }\end{array}$ & $\mathbf{N}$ & t-test length & t-test breadth \\
\hline $\mathbf{5 . 0 0 - 6 . 9 9}$ & 50 & $3.523101^{*}$ & 1.327505 \\
\hline $\mathbf{7 . 0 0 - 8 . 9 9}$ & 50 & $2.972253^{*}$ & $9.959514^{*}$ \\
\hline $\mathbf{9 . 0 0 - 1 0 . 9 9}$ & 50 & 0.4620357 & 0.7692371 \\
\hline $11.00-12.99$ & 50 & $5.361760264^{*}$ & $7.7824860^{*}$ \\
\hline $13.00-14.99$ & 50 & $11.82507^{* *}$ & $11.35604^{*}$ \\
\hline $15.00-16.99$ & 50 & $5.835380^{*}$ & 0.959661 \\
\hline $17.00-18.99$ & 50 & $4.0561622^{*}$ & $5.4220594^{*}$ \\
\hline $19.00-20.99$ & 50 & $4.350231^{*}$ & $5.8881676^{*}$ \\
\hline
\end{tabular}

\section{DISCUSSION}

It has been found that only few studies are available comparing the bilateral asymmetry of foot dimensions. Manna et al. (2001) found no significant difference in foot dimensions between the right and left foot of Bengalee (Indian) female subjects except the foot breadth [7]. For 18 years and above, Nigerian feet are longer and broader in males than in females. Both Nigerian males and females feet had higher mean foot length than that of Cucassians [8]. Similar observation was made by Oladipo et al. (2008) who found right foot 2 to $3 \mathrm{~mm}$ longer and wider, and suggested that the left and right shoe shape should not be symmetrical while designing footwear [9]. Findings from the present studies did not confirm all the results of earlier findings completely, however present study found longer right foot like earlier studies but found left foot broader than the right foot. Maximum intra sample variability is found in foot length in all the age groups.

\section{CONCLUSION}

The study concludes that foot length, foot width (foot size) andfoot index (foot shape of Haryanvi femalesshows statistically significant bilateral differences. Present observation can be used as base line data for the use of forensic science and foot shape is essential for the properly designing of the shoe shape. There are considerable variations for the patterns of growth within human population. Causes of these variations can be understood by conducting such growth studies.

\section{Conflicts of Interests: None}

\section{REFERENCES}

[1]. Deisinger, j., r. Breining, a.: RLER, Of Virtual Environments 2000. (ERGONAUT, Amsterdam, 2000).

[2]. Rout N., Zhang Y.F., Khandual A. and Luxmion A. 3D foot scans to custom shoe last. IJCCT (Special Issue), 2010;1(2,3,4):14-18.

[3]. Krauss I., Grau S., Mauch M., Maiwald C. and Horstmann T. Sex related differences in foot shape. Ergonomics, 2008;51(11):1693-1709.

[4]. Rys M. and Konz S. Adult foot dimensions. In Advances in Industrial Ergonomics and Safety I. A. Mittal (ed). London: Taylor and Francis, 1989;189193.

[5]. Ewunonu E.O., Egwu A.O., Eteudo A.N. and Ajoku K.I. Bilateral foot asymmetry and sexual dimorphism in young adult Igbo people of South-Eastern Nigeria. European Journal of Biotechnology and Bioscience, 2014;1(4):1-5.

[6]. Chantelau E. and Gede A. Foot dimensions of elderly people with and without diabetes mellitus - a data basis for shoe design. Gernotology, 2002;48(4):241-244.

[7]. Manna I., Pradhan D., Ghosh S., Kar S.K. and Dhara P. A comparative study of foot dimension between adult male and female and evaluation of foot hazardsdue to using of footwear. Journal of Physiological Anthropology and Applied Human Science, 2001;20(4):241-246.

[8]. Bob-Manuel I. and Didia B. Sexual dimorphism in foot dimensions among adult Nigerians. The Internet Journal of Biological Anthropology, 2008;3(1):1-6.

[9]. Oladipo G., Bob-Manuel I. and Ezenatein G. Quantitative comparison of foot anthropometry under different weight bearing conditions amongst Nigerians. The Internet Journal of Biological Anthropology, 2008;3(1):1-7.

[10]. Suntnoore D., Karaddi S., Babladi P., Mugadlimath A., Garampalli S.S. and Patil B.S. To study determination of height by foot length in females. International Journal of Current Research and Review, 2013;5(16):15-19.

[11]. Lohman, TG, Roche, AF and Marforell, ER. Anthropometric Standardization Reference Manual. Human Kinetics: Campaign, IL (1988).

[12]. Witana C.P., Xiong S., Zhao J. and Goonetilleke R.S. Foot measurements from three- dimensional scans: A comparison and evaluation of different methods. International Journal of Industrial Ergonomics, 2006;36:789-807.

[13]. JungS., Lee S., Boo J. and Park J. A classification of foot types for designing footwear of the Korean elderly. Proceedings of the 5th Symposium on Footwear Biomechanics. E.M. Hennig and A. Stacoff (eds).Switzerland: Dept. of Materials, ETH Zürich, 2001;48-49.

[13]. Wolanski, N. The methods of the control of the physical development of children and youth. Panstwowe Zaklady Wadawinctw Lekarskich, Warszawa (1965). 